\title{
Improved Traditional Phytomedicines in Current Use for the Clinical Treatment of Malaria
}

Author

Affiliations
Merlin Willcox ${ }^{1,2}$

${ }^{1}$ Department of Primary Health Care, University of Oxford, Oxford, UK

2 Research Initiative on Traditional Antimalarial Methods, Oxford, UK
Key words

- malaria

- herbal medicine

- phytomedicine

- government-approved

- clinical trials received June 25, 2010

revised October 7,2010

accepted October 23, 2010

Bibliography

Dol http://dx.doi.org/

10.1055/s-0030-1250548

Published online January 3,

2011

Planta Med 2011; 77: 662-671

(c) Georg Thieme Verlag KG

Stuttgart · New York .

ISSN 0032-0943

\section{Correspondence}

\section{Dr. Merlin Willcox}

Department of Primary

Health Care

Old Road Campus,

Roosevelt Drive

Oxford OX3 7LF

United Kingdom

Phone: +441865289288

Fax: +441865289287

merlin.willcox@dphpc.ox.ac.uk

\section{Abstract}

$\nabla$

Phytomedicines and "green pharmacies" are promoted by some NGOs and governments as part of their efforts to control malaria. "Improved traditional medicines" (ITMs) are standardised as regards preparation and dose, although not always according to the concentration of active compounds. A systematic literature search revealed that six such phytomedicines are currently government-approved in at least one country and

\section{Introduction}

$\nabla$

In spite of many valiant efforts at control and even elimination, malaria remains one of the top five causes of childhood deaths in the world. Artemisinin combination therapies (ACTs) are now recommended by the World Health Organization (WHO) as first-line treatments [1], but are still not widely available to those who most need them, especially in remote areas. It is estimated that $80 \%$ of malaria patients are treated in the community and never come to any formal health facility [2].

Growing medicinal plants in a "green pharmacy", for preparation at the local level (usually as herbal teas), can empower poor communities to become more self-reliant. Several Non-Governmental Organizations (NGOs) promote this approach because it has the advantage of being cheap, sustainable, available at the point of need, and does not rely on the fickle goodwill of donor agencies or on unreliable distribution networks. However, there must also be good evidence of safety and efficacy for the plants used. In a malarious area, one of the top priorities for a "green pharmacy" will always be antimalarial plants. Worldwide, over 1200 plant species are reportedly used for the treatment of malaria and fever [3]. Although many of these have been tested in the laboratory used on a relatively large scale nationally or internationally: Artemisia annua L. (Asteraceae), Cinchona bark (Rubiaceae), Cryptolepis sanguinolenta (Lindl.) Schltr. (Apocynaceae), "Ayush-64”, “Malarial-5" and Cochlospermum planchonii Hook. f. ex Planch. (Bixaceae). One further ITM has been developed and is in the process of being approved: Argemone mexicana decoction. Their development, phytochemistry, pharmacology, and clinical trials are reviewed, as well as priorities for future research. with varying results, very few have been evaluated in clinical trials [4].

Another approach is the production of standardised phytomedicines at the national level, often developed by a government-sponsored research organisation. These phytomedicines, often called "improved traditional medicines" (ITMs), are standardised as regards preparation and dose, although not always according to the concentration of active compounds. In this model, the preparation can be more complex (whether a complex mixture of plants or a more complex extraction procedure) and quality control is easier to implement. The country benefits by having a locally produced medicine which is more sustainable than imports. However, the problems of distribution and lack of infrastructure remain; and the finished product will not necessarily be cheaper than a highly subsidised ACT.

The Research Initiative on Traditional Antimalarial Methods (RITAM) (www.giftsofhealth/ritam) was established in 1999 to examine such questions and has conducted many systematic reviews on antimalarial plants [5]. This review will summarise the evidence for safety and efficacy of government-approved improved traditional phytomedicines in current clinical use for the treatment of malaria. 


\section{Methods}

$\nabla$

A literature search was performed using MEDLINE, CAB, SOCIOFILE, and EMBASE to find all articles referring to traditional herbal remedies for malaria (key words: "malaria", "traditional medicine", "malaria-therapy"). References of relevant articles were searched, and some journals were searched by hand to try to identify as many relevant articles as possible. The RITAM network (consisting of over 200 researchers in the field of traditional antimalarials) was consulted and conferences attended in an attempt to identify unpublished studies on herbal antimalarials. For the purposes of this review, we selected only "improved traditional medicines" which are government-approved in at least one country and which have been deployed at a relatively large scale (national or international).

\section{Results}

$\nabla$

Six "improved traditional medicines" were identified which are government-approved, have been used on a relatively large scale and have been the subject of published research, and one further ITM which is in the process of being approved. Their composition is summarised in $\odot$ Table 1, preclinical efficacy in - Table 2, and clinical efficacy (in uncomplicated P. falciparum malaria) in 0 Table 3.

\section{Qinghao (Artemisia annua L. [Asteraceae])}

Development and use of the phytomedicine: The earliest record of the medicinal use of "qing hao" dates back to $168 \mathrm{BC}$ in the "Fiftytwo prescriptions", which recommended it for the treatment of

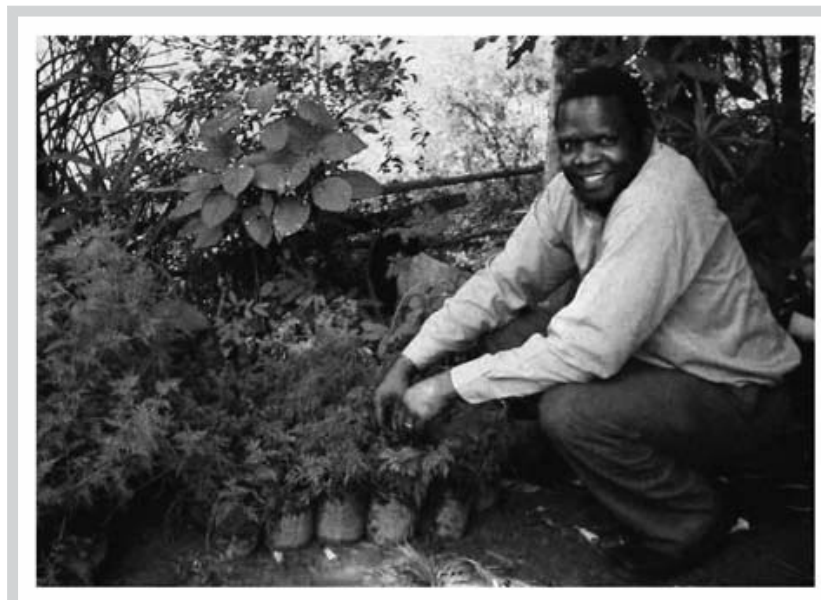

Fig. 1 Pastor George Okuto is one of Anamed's local partners in Kisumu, Kenya. He has distributed seedlings of Artemisia annua to over 200 families for use in their herbal home gardens (reproduced by the author).

haemorrhoids [6]. Ge Hong was the first to recommend "qing hao" for the treatment of "intermittent fevers" (many of which were probably malaria). His "Handbook of Prescriptions for Emergency Treatment", written in $340 \mathrm{AD}$, recommends the following preparation: "Take a bunch of qing hao and two sheng (two times $0.2 \mathrm{~L}$ ) of water for soaking it, wring it out to obtain the juice and ingest it in its entirety" [7].

Although there is some debate as to whether "qing hao" was in fact Artemisia annua or A. apiacea [7], it was from A. annua that

Table 1 Government-approved improved traditional phytomedicines in current clinical use for the treatment of malaria.

\begin{tabular}{|c|c|c|c|c|c|c|c|}
\hline Remedy & Species & Part & Preparation & $\begin{array}{l}\text { Country } \\
\text { of origin }\end{array}$ & $\begin{array}{l}\text { Year } \\
\text { developed }\end{array}$ & $\begin{array}{l}\text { Countries } \\
\text { where currently used }\end{array}$ & $\begin{array}{l}\text { Level of } \\
\text { production }\end{array}$ \\
\hline Qing hao & $\begin{array}{l}\text { Artemisia annua L. } \\
\text { (Asteraceae) }\end{array}$ & aerial parts & infusion & China & 340 & $\begin{array}{l}\text { China, Vietnam, } \\
\text { throughout Africa }\end{array}$ & local \\
\hline Totaquina & Cinchona spp (Rubiaceae) & bark & decoction & Peru & 1649 & $\begin{array}{l}\text { India, Madagascar, Sudan, } \\
\text { Bolivia, Colombia, Nicaragua }\end{array}$ & $\begin{array}{l}\text { local } \\
\text { and national }\end{array}$ \\
\hline Phyto-laria & $\begin{array}{l}\text { Cryptolepis sanguinolenta } \\
\text { (Lindl.) Schltr. } \\
\text { (Apocynaceae) }\end{array}$ & roots & decoction & Ghana & 1974 & Ghana & $\begin{array}{l}\text { local } \\
\text { and national }\end{array}$ \\
\hline \multirow[t]{3}{*}{ Ayush-64 } & $\begin{array}{l}\text { Caesalpinia bonducella (L.) } \\
\text { Fleming (Fabaceae) } \\
\text { Swertia chirata Buch. Ham } \\
\text { (Gentianaceae) }\end{array}$ & $\begin{array}{l}\text { roots } \\
\text { seed pulp } \\
\text { whole plant }\end{array}$ & $\begin{array}{l}\text { decoction } \\
\text { dry powder } \\
\text { decoction }\end{array}$ & \multirow[t]{3}{*}{ India } & \multirow[t]{3}{*}{1980} & \multirow[t]{3}{*}{ India } & \multirow[t]{3}{*}{ national } \\
\hline & $\begin{array}{l}\text { Alstonia scholaris (L.) R. Br. } \\
\text { (Apocyanaceae) }\end{array}$ & bark & decoction & & & & \\
\hline & $\begin{array}{l}\text { Picrorhiza kurrooa Royle ex } \\
\text { Benth. (Plantaginaceae) }\end{array}$ & rhizome & decoction & & & & \\
\hline \multirow[t]{3}{*}{ Malarial-5 } & $\begin{array}{l}\text { Cassia occidentalis L. } \\
\text { (Caesalpinaceae) (62\%) }\end{array}$ & leaves & decoction & \multirow[t]{3}{*}{ Mali } & \multirow[t]{3}{*}{1982} & \multirow[t]{3}{*}{ Mali } & \multirow[t]{3}{*}{ national } \\
\hline & $\begin{array}{l}\text { Lippia chevalieri Mold } \\
\text { (Verbenaceae) (32\%) }\end{array}$ & leaves & decoction & & & & \\
\hline & $\begin{array}{l}\text { Spilanthes oleraceae L. } \\
\text { (Compositae) }(6 \%)\end{array}$ & flowerheads & decoction & & & & \\
\hline N'dribala & $\begin{array}{l}\text { Cochlospermum planchonii } \\
\text { Hook. f. ex Planch. } \\
\text { (Bixaceae) }\end{array}$ & root & decoction & $\begin{array}{l}\text { Burkina } \\
\text { Faso }\end{array}$ & 2005 & $\begin{array}{l}\text { Burkina Faso, Ivory Coast, } \\
\text { Nigeria }\end{array}$ & $\begin{array}{l}\text { local } \\
\text { and national }\end{array}$ \\
\hline $\begin{array}{l}\text { Soumafoura } \\
\text { Tiemoko Bengaly }\end{array}$ & $\begin{array}{l}\text { Argemone mexicana } \mathrm{L} . \\
\text { (Papaveraceae) }\end{array}$ & aerial parts & decoction & Mali & 2006 & Mali & $\begin{array}{l}\text { local } \\
\text { and national }\end{array}$ \\
\hline
\end{tabular}


Table 2 Summary of preclinical efficacy of antimalarial improved traditional medicines.

\begin{tabular}{|c|c|c|c|c|c|c|}
\hline \multirow[t]{2}{*}{ Remedy* } & \multicolumn{2}{|c|}{ In vitro against $P$. falciparum } & \multicolumn{2}{|l|}{ In vivo in mice ( $P$. berghei) } & \multirow[b]{2}{*}{ Dose ${ }^{* *}$} & \multirow[t]{2}{*}{ References } \\
\hline & $\mathrm{IC}_{50}(\mu \mathrm{g} / \mathrm{mL})$ & Extract & $\%$ parasite suppression & Extract & & \\
\hline Qing hao & 1.5 & ethanolic & 33.3 & aqueous infusion & $\begin{array}{l}8.3 \mathrm{~mL} / \mathrm{kg} \text { bd } \\
\text { po for } 7 \mathrm{~d}\end{array}$ & {$[20,24,86]$} \\
\hline Totaquina & $<10$ & ethanolic & 100 & ethanolic & $\begin{array}{l}500 \mathrm{mg} / \mathrm{kg} \text { od } \\
\text { po for } 4 \mathrm{~d}\end{array}$ & {$[26,87]$} \\
\hline Phyto-laria & $<6$ & ethanolic & 59 & ethanolic & $\begin{array}{l}100 \mathrm{mg} / \mathrm{kg} \text { od } \\
\text { po for } 4 \mathrm{~d}\end{array}$ & {$[43,53]$} \\
\hline Ayush-64 & no data & & 0 & as per Table 1 & $1.5 \mathrm{~g}$ od for $5 \mathrm{~d}$ & {$[54,55,88]$} \\
\hline Malarial-5 & $470-600$ & $\begin{array}{l}\text { aqueous } \\
\text { decoction }\end{array}$ & 55 & $\begin{array}{l}\text { aqueous decoc- } \\
\text { tion, lyophilised }\end{array}$ & $\begin{array}{l}200 \mathrm{mg} / \mathrm{kg} \text { od } \\
\text { po for } 5 \mathrm{~d}\end{array}$ & [63] \\
\hline N'dribala & 75 & $\begin{array}{l}\text { aqueous root } \\
\text { decoction }\end{array}$ & no data & & & {$[71]$} \\
\hline $\begin{array}{l}\text { Soumafoura Tiemoko } \\
\text { Bengaly }\end{array}$ & 5.89 & aqueous & 0 & aqueous decoction & $\begin{array}{l}375-3375 \mathrm{mg} / \mathrm{kg} \\
\text { po }\end{array}$ & {$[75,78,79,84]$} \\
\hline
\end{tabular}

* Plant species and parts as per $\bigcirc$ Table $1 .{ }^{* *}$ od = once daily; bd = twice daily; po = per os (i.e., oral)

Table 3 Summary of clinical trials of antimalarial improved traditional medicines for the treatment of uncomplicated P. falciparum malaria.

\begin{tabular}{|c|c|c|c|c|c|c|c|c|}
\hline Remedy* & Dose $^{* *}$ & $\begin{array}{l}\text { Location } \\
\text { of trial }\end{array}$ & Season & $\begin{array}{l}\text { Total } n \text { of } \\
\text { patients (P.f.) }\end{array}$ & $\begin{array}{l}\text { Mean age } \\
\text { of patients } \\
\text { (range, } \\
\text { in years) }\end{array}$ & $\begin{array}{l}\text { Parasite } \\
\text { clearance at } \\
\text { d 5-7 } \\
\text { (\% of patients) }\end{array}$ & $\begin{array}{l}\text { Recrudescence } \\
\text { by } \mathrm{d} 28 \\
\text { (\% of patients) }\end{array}$ & References \\
\hline Qing hao & $\begin{array}{l}\text { 5-9 g dried leaf infused } \\
\text { in } 1 \mathrm{l} \text { boiling water, } 250 \mathrm{~mL} \\
\text { qds for } 7 \mathrm{~d}\end{array}$ & $\begin{array}{l}\text { Democratic } \\
\text { Republic of } \\
\text { Congo }\end{array}$ & $\begin{array}{l}\text { whole } \\
\text { year }\end{array}$ & 379 & $(\geq 18)$ & 70-100 & $13-39$ & [89-91] \\
\hline Totaquina & $1.2 \mathrm{~g}$ daily for $5 \mathrm{~d}$ & $\begin{array}{l}\text { Algeria, Bulgaria, } \\
\text { China, France, } \\
\text { India, Italy, } \\
\text { Malaysia, } \\
\text { Morocco, } \\
\text { Romania, Spain }\end{array}$ & rainy & 586 & not reported & $92-100$ & no data & {$[26,35,37]$} \\
\hline Phyto-laria & $\begin{array}{l}2.5 \mathrm{~g} \text { root powder per } \\
\text { teabag, infused in } 150 \mathrm{~mL} \\
\text { of boiling water for } 5-10 \\
\text { mins, tds for } 5 \text { days }\end{array}$ & Ghana & & 58 & adult & 100 & 0 & {$[45,53]$} \\
\hline Ayush-64 & $0.5-1 \mathrm{~g}$ tds for $3 \mathrm{~d}$ & $\begin{array}{l}\text { Madhya Pradesh, } \\
\text { India }\end{array}$ & $\begin{array}{l}\text { end of } \\
\text { rains }\end{array}$ & 4 & $22(7-35)$ & 100 & no data & [57] \\
\hline Malarial-5 & $\begin{array}{l}10 \mathrm{~g} \mathrm{bd} \text { for } 4 \mathrm{~d} \\
\text { then od for } 3 \mathrm{~d}\end{array}$ & $\begin{array}{l}\text { Sélingué and } \\
\text { Bamako, Mali }\end{array}$ & $\begin{array}{l}\text { rainy } \\
\text { season; } \\
\text { dry } \\
\text { season }\end{array}$ & 92 & $(5-60)$ & 0 & no data & [64-66] \\
\hline N'dribala) & $\begin{array}{l}50 \mathrm{~g} \text { dried root powder } \\
\text { boiled in } 1500 \mathrm{~mL} \\
\text { water for } 10 \text { minutes; } \\
200 \mathrm{~mL} \text { tds for } 5 \text { days }\end{array}$ & $\begin{array}{l}\text { Banfora, Burkina } \\
\text { Faso }\end{array}$ & rainy & 46 & $23(12-45)$ & 52 & no data & [67] \\
\hline $\begin{array}{l}\text { Soumafoura } \\
\text { Tiemoko } \\
\text { Bengaly }\end{array}$ & $\begin{array}{l}500 \mathrm{~g} \text { dried aerial parts } \\
\text { boiled in } 5 \mathrm{~L} \text { water for } 3 \\
\text { hours, taken as } 250 \mathrm{~mL} \\
\text { bd over } 7-14 \text { days }\end{array}$ & Sikasso, Mali & rainy & 215 & $10(0-65)$ & 19 & $63 \%$ & {$[78,79,84]$} \\
\hline
\end{tabular}

* Preparations used in clinical trials are those given in $\odot$ Table $1 .{ }^{*}$ tds $=3$ times a day; $q d s=4$ times a day

Chinese scientists isolated artemisinin, the most powerful antimalarial compound ever discovered, in 1971. Since then, several NGOs have recommended the use of Artemisia annua as a herbal remedy ( $\bullet$ Fig. 1). Anamed (Action for Nature and Medicine, www.anamed.org) has distributed seeds of a recently developed artemisinin-rich genetic variety of Artemisia annua [8] for cultivation and preparation as a herbal antimalarial to 240 partner organisations in developing countries. Other NGOs such as IFBV in Luxembourg (http://www.iwerliewen.org/) and ICEI in Italy (http://www.icei.info/) are involved in similar programmes. Arte- misia annua leaf infusion was officially approved by the Ministry of Health in the Democratic Republic of Congo in 2007.

The doses recommended by Anamed are based on the Chinese pharmacopoeia: an infusion of $5 \mathrm{~g}$ dried leaves on which $1 \mathrm{~L}$ of boiling water is poured and left to cool for 15 minutes, of which $250 \mathrm{~mL}$ is taken every six hours for seven days. A reduced dose is recommended for children, according to weight [9]. However, alternative preparations may be more effective. The most effective preparation in the literature was a crude ethanolic extract suspended in oil and presented in capsules [10]. A similar prepara- 
tion is currently being developed by the Equator Foundation in the Netherlands (http://artemisia-for-all.org/). Preliminary studies show this can provide a much larger dose of artemisinin in a much smaller volume than the tea. Other suggestions are to use dried $A$. annua powder mixed in porridge, biscuits, or honey, to improve palatability for young children [11].

Phytochemistry and pharmacology: Artemisia annua contains many different classes of compounds: at least 28 monoterpenes, 30 sesquiterpenes, 12 triterpenoids and steroids, 36 flavonoids, 7 coumarins, 4 aromatic and 9 aliphatic compounds [12]. Several of these have some antimalarial activity, but the most active is undoubtedly the sesquiterpene lactone artemisinin, found in the leaves and flowers. Artemisinin has been found in only two other species, Artemisia apiacea and A. lancea [13]. Some other sesquiterpenes occur in much greater concentrations than artemisinin in wild strains of the plant: arteannuin $B(2-4 \times)$ and artemisinic acid $(7-8 \times)$. Arteannuin $B$ used alone is ineffective and toxic in rat malaria, but it potentiates the effect of artemisinin [14]. A. annua also produces at least 36 flavonoids, five of which have been shown selectively to potentiate the in vitro activity of artemisinin against Plasmodium falciparum [15]. Casticin, at a concentration of $5 \mu \mathrm{mol} / \mathrm{L}$, induces a 3 - to 5 -fold reduction in the $\mathrm{IC}_{50}$ for artemisinin [16]. Chrysosplenol-D has the strongest potentiating effect, and this is also the most abundant flavone in plant material [15]. An aqueous infusion can extract up to $86 \%$ of the artemisinin into the water, whereas as little as $30 \%$ is extracted in a decoction (when the plant is boiled in water for several minutes), because artemisinin is not heat-stable [17]. Using full fat milk rather than water can increase the proportion of artemisinin extracted [18]. Recent research has shown that the traditional method of soaking then wringing out or pounding the juice of the plant results in much higher artemisinin concentrations than the infusion (up to $293 \mathrm{mg} / \mathrm{L}$ compared to $14.5 \mathrm{mg} / \mathrm{L}$, respectively), although the extraction efficiency (total amount of artemisinin extracted) is less (14.9\% compared to $53.8 \%$, respectively) [19].

In vivo and in vitro studies have also shown that the whole Artemisia annua extract has a much greater antimalarial activity than the equivalent dose of artemisinin $[19,20]$. Furthermore the bioavailability of artemisinin from a crude plant extract is much greater than from pure tablets (Rezelman, unpublished data).

Artemisinin has now been used in several million patients, with only one report of neurological side effects following artesunate treatment $[21,22]$. Artemisinin is generally considered to be safe in the second and third trimesters of pregnancy [22] and now artesunate is recommended as the first line treatment for pregnant women with severe malaria [1]. However, early studies showed that relatively low doses of artemisinin (13-25 mg/kg or $1 / 200$ $1 / 400$ of the LD50) cause fetal resorption in rodents, therefore use in the first trimester is not recommended [23] except in severe cases [1].

Clinical trials: Ethanolic extracts have been tested mainly against $P$. vivax in China, but the results seem promising, with $100 \%$ parasite clearance and fever clearance reported although recrudescence occurred in up to $33 \%[10,14]$. One study claimed a $100 \%$ "cure" rate for $P$. falciparum malaria [14].

Herbal infusions (according to the Anamed recipe) are the preparation most widely tested in Africa, in six trials. These report rates of parasite clearance ranging from $70 \%$ to $100 \%$, with recrudescence rates up to 39\% [24] ( Table 2). The only side-effect reported was nausea in 3-25\% of patients. However, none of these studies included children, who are the group at greatest risk of severe malaria and death. A recent pilot pharmacovigilance study

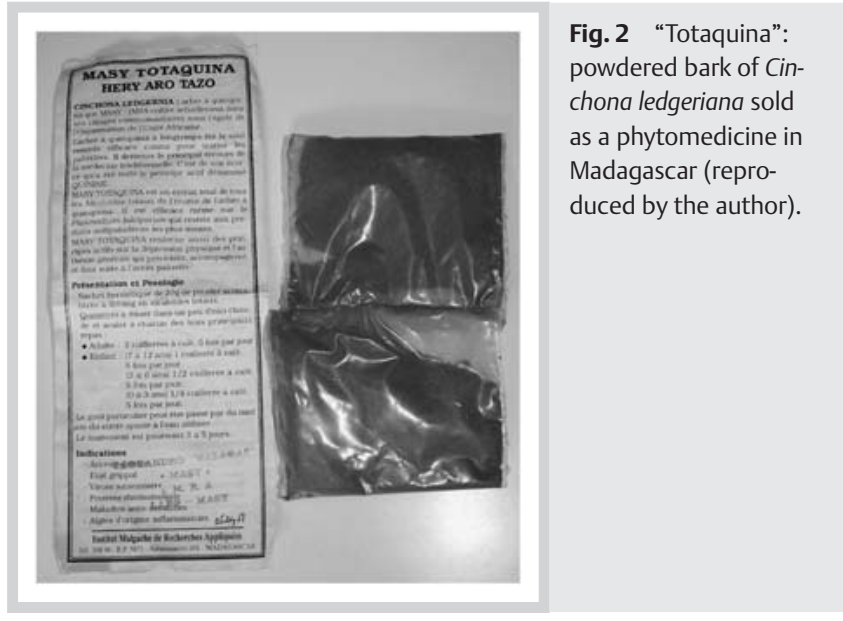

has confirmed that the only significant adverse event observed was that of miscarriage in the first trimester of pregnancy [25].

\section{Totaquina (bark of Cinchona species [Rubiaceae])}

Development and use of the phytomedicine: It is not known how long Cinchona bark had been used by indigenous communities in South America before its "discovery" by Jesuit priests in Peru in the early part of the 17th century [26]. Indeed, it is not known whether malaria even existed there before the arrival of European settlers. The first probable reference to the use of Cinchona in medical practice came in Belgium in 1643, when a public health official in Ghent recommended a powder, Pulvis indicus, for the treatment of tertian fevers [27]. The first indisputable reference, however, is the Schedula Romana, a handbill issued by the Pharmacy of the Collegio Romano in 1649 and again in 1651, containing precise instructions on dosage and administration. In 1649, at a gathering in Rome of the Jesuit Order, the influential Spanish Cardinal Juan de Lugo recommended the powder to the assembled delegates, ensuring the remedy's dissemination to missions throughout Europe [28]. In the nineteenth century, colonial powers established plantations of Cinchona throughout the tropics [29]. Today Cinchona trees are still cultivated in many parts of the tropics, for example the Congo, Madagascar, Guatemala, the Philippines, Vietnam, Indonesia and India.

Several crude extracts of Cinchona bark were in common use in the first half of the 20th century [26]. Totaquina type I (or quinetum) was prepared as a total alkaloid extract of $C$. succirubra Pav. Ex Klotzsch (Rubiaceae) or C. robusta (Rubiaceae) by dissolving the soluble constituents of powdered bark with hydrochloric acid, then precipitating the alkaloids with sodium hydroxide and drying the crude deposit. Totaquina type II (or residual alkaloids) was left over from the bark of $C$. ledgeriana (Howard) Bern. Moens ex Trimen (Rubiaceae) after the extraction of quinine. Sometimes "Cinchona febrifuge" was made from the total alkaloids of $C$. ledgeriana, without the prior extraction of quinine. Today, a processed powder of $C$. ledgeriana bark is still sold as a phytomedicine in Madagascar under the name of "Totaquina" by the Institut Malgache de Recherches Appliquées (๑ Fig. 2).

Phytochemistry and pharmacology: Almost 30 alkaloids have now been described in Cinchona bark [30], several of which are active against plasmodia in vitro, and some of which are not [31]. The four best-known alkaloids are quinine with its $d$-isomer quinidine, and cinchonine with its $l$-isomer cinchonidine, all of which have antiplasmodial activity. They are found in varying propor- 
tions in different barks. Interestingly, quinine is not the most potent of the alkaloids: quinidine, dihydroquinidine, and cinchonine all have a consistently lower $\mathrm{IC}_{50}$ in vitro. The combination of quinine with quinidine and cinchonine is $2-10$ times more effective against quinine-resistant strains, and the mixture of alkaloids has a more consistent effect than any of the alkaloids used singly [32]. Cinchonine also inhibits P-glycoprotein, a transmembrane pump which pumps toxins (including drugs) out of cells, and is overexpressed in cancer cells, contributing to multidrug resistance. Cinchonine has been used to good effect in combination with chemotherapy for patients with lymphoproliferative syndromes [33]. It is possible that similar mechanisms are involved in malaria drug resistance [34], and cinchonine may therefore be able to counteract this.

Clinical trials: Several clinical trials were conducted of crude Cinchona preparations in India in the 1920s and 1930s [26]. The largest was a multicentre trial of totaquina conducted under the auspices of the League of Nations in 1933 [35]. 421 patients were given totaquina type I, and 634 were given totaquina type II. The outcome measure was parasite and fever clearance on the fifth (and last) day of treatment; there was no further follow-up to look for relapses. There was an attempt at standardising the composition of the totaquina used and the doses administered, but there was still quite a wide variation in the actual doses given. In spite of the variation in dosage, the parasite clearance achieved was surprisingly uniform, and as good as quinine. As regards safety, the League of Nations concluded that "the case records contain no cogent evidence that Totaquina is more toxic than quinine in the doses given" [36].

A small trial published in 1935 compared the response of $P$. falciparum infections to treatment with either quinine, totaquina type I (42 patients) or type II (31 patients). They found no significant difference in parasite or fever clearance times between the groups, with $100 \%$ clearance of both fever and parasites by day 4 of treatment [37]. Unfortunately there was no longer term follow-up to look at relapse rates. No further clinical trials of totaquina have been published since 1935 . However, trials on individual Cinchona alkaloids have shown that they are all effective antimalarials. Quinidine is at least as effective as quinine and more so in the case of resistant infections [38]. Cinchonine and cinchonidine, when used in isolation, are also as effective as quinine $[39,40]$. A standardised mixture of Cinchona alkaloids has been developed and marketed as "Quinimax" (71.4\% quinine with $18.6 \%$ quinidine and $5 \%$ cinchonine). It is as effective as quinine in the treatment of malaria, but with a lower incidence of side-effects [41]. There have been no published studies comparing its efficacy with that of quinine in areas with significant quinine resistance.

Cryptolepis sanguinolenta (Lindl.) Schltr. (Apocynaceae) Development and use of the phytomedicine: Cryptolepis sanguinolenta (Lindl.) Schltr. (Apocynaceae) is a scrambling shrub native to West Africa and used for the treatment of malaria in Ghana and in the Democratic Republic of Congo [42,43]. In 1974, C. sanguinolenta was introduced to the Centre for Scientific Research into Plant Medicine (CSRIPM) in Mampong-Akwapim, Ghana. Decoctions of the roots of this plant have since then been used to treat malaria and some bacterial infections [44]. It has been developed and sold in standardized teabags under the brand name of "Phyto-laria" by the company Phyto-Riker (- Fig. 3) and is approved by Ghana's drug regulatory agency, the Food and Drugs Board [45]. Each teabag contains $2.5 \mathrm{~g}$ of

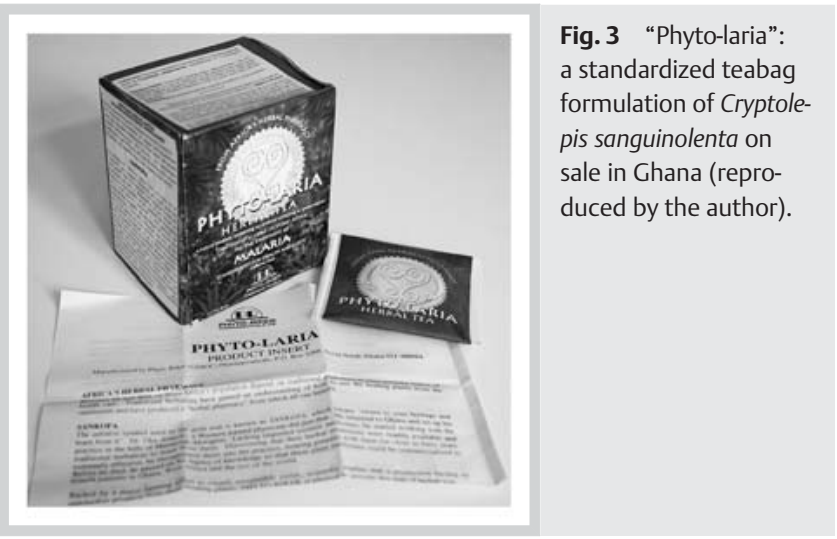

Cryptolepis root powder and is also standardized using total content of alkaloids. Instructions to patients are to steep the teabag in one cup (about $150 \mathrm{~mL}$ ) of boiling water for 5-10 minutes and to take one cup three times a day for 5 days. WHO is currently collaborating with CSRIPM to develop a standardized form of the extract for use in African countries [46].

Phytochemistry and pharmacology: The roots of $C$. sanguinolenta contain approximately $0.5 \%$ of alkaloids [47]. The major alkaloid is cryptolepine, an $\mathrm{N}$-methyl derivative of the indoloquinoline compound, quindoline. In vitro this alkaloid has antimalarial activity comparable to chloroquine $[48,49]$. However cryptolepine intercalates into DNA [50] and causes cell death by inhibiting the action of poly (ADP-ribose) polymerase [51]. Daily administration of $30 \mathrm{mg} / \mathrm{kg}$ cryptolepine to mice resulted in extensive necrosis of liver cells after 6 weeks but not after 2 weeks [52].

Ethanolic extracts of the root are very effective against $P$. falciparum in vitro and against $P$. berghei in vivo ( $\odot$ Table 2 ). In an acute toxicity assessment of this product, up to $2 \mathrm{~g} / \mathrm{kg}$ body weight of the dry extract (corresponding to 1754-fold the human dose of the product) was given orally to groups of mice, rats, and rabbits. No adverse effects were observed in any of the animals [46].

Clinical trials: A controlled clinical trial compared an aqueous root extract of Cryptolepis sanguinolenta with chloroquine in patients with P. falciparum malaria [53]. Twelve patients were treated with Cryptolepis extract $(25 \mathrm{mg} / \mathrm{kg}$ body weight three times daily) and 10 were given chloroquine ( $25 \mathrm{mg} / \mathrm{kg}$ over 3 days). Parasite clearance time was only one day longer than with chloroquine (3.3 vs. 2.2 days) and symptom clearance was faster (36 vs. 48 hours). Fewer side effects were reported by patients taking the extract than by those on chloroquine. No significant changes were detected in the blood and urine samples analysed. No cases of recrudescence were reported in any of the participants in the follow-up 28-day period. A larger trial in 46 patients confirmed a parasite clearance time of $82.3 \mathrm{~h}$ and a fever clearance time of $25.4 \mathrm{~h}[45]$.

\section{Ayush-64}

Development and use of the phytomedicine: Widespread resurgence of malaria in India during the 1970s prompted the Indian government to develop an Ayurvedic remedy for malaria. Scientists at the Central Council for Research in Ayurveda and Siddha (CCRAS), an autonomous institution of the Ministry of Health and Family Welfare, selected four plants to prepare a formulation named "Ayush-64". CCRAS further developed the drug in collaboration with 20 laboratories in the country and patented Ayush-64 
as a new antimalarial herbal compound. The herbs were all traditionally used for the treatment of fevers including malaria [54]. Aqueous decoctions of the constituent herbs ( Table 1) are prepared separately, then boiled to reduce the volume, cooled and filtered. The filtrate is then evaporated to dryness by steam. The powders obtained from the aqueous extract are meshed (two parts of $C$. bonducella seed pulp and one part of all the others) and mixed with adhesives like starch and gum acacia. Tablets of $500 \mathrm{mg}$ are strip packed. The recommended dosages are as follows: adults should take $1 \mathrm{~g}$ ( 2 tablets) three times a day for 5 to 7 days. For children aged 5-12 years, the dose is $500 \mathrm{mg}$ twice daily for 5-7 days, and for infants below 5 years, $1 / 2$ tablet of $500 \mathrm{mg}$ powdered and mixed with honey twice a day for 5-7 days [54].

Ayush-64 was used on a large scale in public health programmes in the 1980s [55], but this has been scaled back since the results of recent clinical trials were deemed unsatisfactory [54,56]. However, very similar preparations are still produced by Ayurvedic companies in India.

Phytochemistry and pharmacology: The active principles of Alstonia scholaris (echitamine chloride), Swertia chirata (swerchirin), and Caesalpinea bonducella ( $\beta$-caesalpin) have been tested on albino rats infected with $P$. berghei. Echitamine chloride was effective at $320 \mathrm{mcg} / \mathrm{kg}$ subcutaneously, $\beta$-caesalpin was effective at $1.6 \mathrm{mg} / \mathrm{kg}$ orally, and swerchirin was effective at both levels and by both routes [55]. However, mouse studies of Ayush-64 itself revealed that there was neither any decrease in parasitaemia nor any increase in the survival time [55]. The acute and subacute toxicity animal studies showed Ayush-64 was safe even at high dosages (100 mg to $10 \mathrm{~g} / \mathrm{kg}$ ), so it was recommended for clinical trials.

Clinical trials: Almost all clinical trials of Ayush-64 have been conducted on patients with P. vivax malaria $[4,55,56]$. Only one trial included patients with $P$. falciparum malaria, and in even in this trial there were only four patients with asexual $P$. falciparum parasites [57] ( Table 3). Several uncontrolled field trials found that $82-86 \%$ of patients were cleared of $P$. vivax parasites by day $7-9[55,57]$. Four randomised controlled trials have been carried out, of which three were double-blind [4]. These showed that parasite clearance was achieved by day 6 in $72-95 \%$ of patients [55], but there was significant recrudescence so that by day 28 , only $48.9 \%$ of patients remained free of parasites (compared to $100 \%$ of those treated with chloroquine) [56]. Two studies suggested that symptomatic improvement was good [55] whereas the third reported that it was slower with Ayush-64 than with chloroquine, and that patients complained about the frequency and duration of dosing and the size of the tablets [56].

\section{Malarial-5}

Development and use of the phytomedicine: "Malarial" was first formulated by Prof. Mamadou Koumaré at the Department for Traditional Medicine in Mali, based on a recipe used in his family. It has been produced as an "improved traditional phytomedicine" in Mali since 1982, and is now government-approved and included in the Malian National Formulary [58] as a treatment for fevers and malaria in patients aged 15 years and above.

Phytochemistry and pharmacology: Cassia occidentalis L. (Caesalpinaceae) is a pantropical plant widely used for the treatment of malaria [59] and is active in vitro against malaria parasites [60]. Lippia chevalieri Mold. (Verbenaceae) is an aromatic herb which is used in West Africa to flavour tea and treat fevers [61]. Spilanthes oleracea L. (Asteraceae) is a sprawling plant with yellow

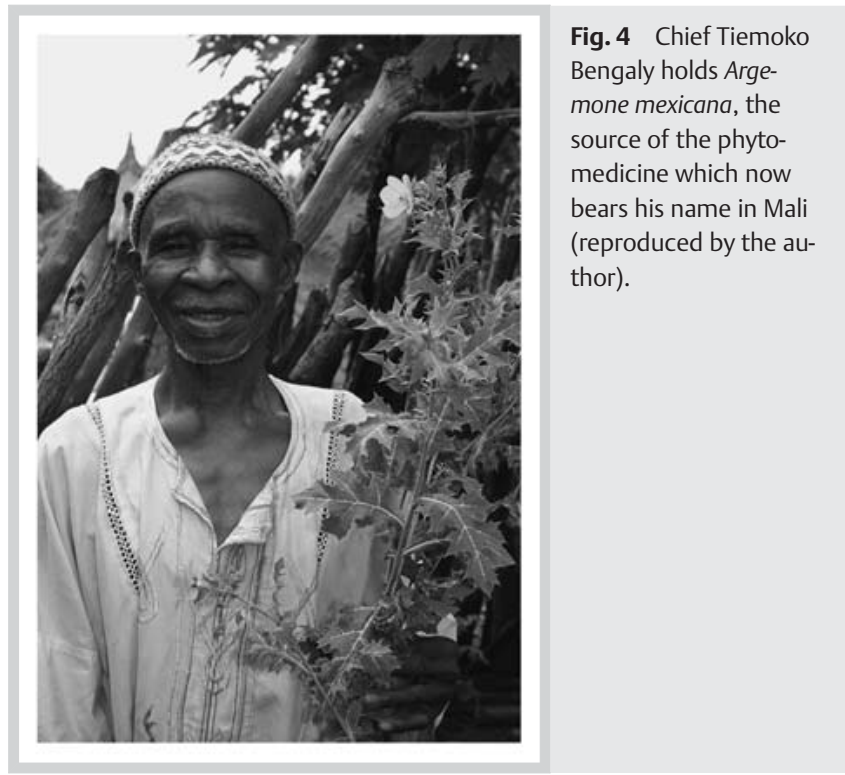

flowers which have a variety of uses in traditional medicine, including as a local anaesthetic for toothache, and as an antipyretic. They contain spilanthol, which is effective against Plasmodium falciparum [62]. "Malarial" was evaluated against malaria parasites in vitro and in mice. It was not very active in vitro $\left(\mathrm{IC}_{50}=470-600 \mu \mathrm{g} / \mathrm{ml}\right)$ but prolonged the survival of malaria-infected mice by 2-3 days compared to the untreated controls [63]. It was also non-toxic to mice.

Clinical trials: Three clinical studies were carried out to evaluate the safety and efficacy of Malarial. The first was a randomised controlled trial comparing it to chloroquine [64]. There were 53 patients included, of which 36 were randomised to "Malarial" and 17 to chloroquine. Follow-up to day 21 was completed by $75 \%$ of the Malarial group, and $59 \%$ of the chloroquine group. Fever clearance was not significantly different between the two groups. However, parasite clearance was better in the chloroquine group, but there was still a substantial reduction in parasitaemia in the Malarial group (geometric mean $=17975$ at day 0 and 154 at day 7). Malarial was better tolerated than chloroquine. A second comparative study was conducted one year later, with the same inclusion criteria, except that patients were required to have a temperature of $38^{\circ} \mathrm{C}$ or higher. Fifty-three patients were included, and parasitaemia at inclusion was higher than in the first study (geometric mean 46024 at day 0). The reduction in parasitaemia was slower for patients on Malarial, and their mean parasitaemia never went below 5000 parasites $/ \mathrm{mm}^{3}$ [65]. The higher initial parasitaemia in this study may explain the poorer result than in the first study. Patients in this study were febrile at inclusion, with high parasite counts, so their immunity to malaria may have been less than that of the patients in the first study. It was felt that the amount of Spilanthes oleraceae (4\%) present in this formulation of Malarial was insufficient for a truly effective schizonticidal activity.

It was therefore decided to increase the amount of Spilanthes oleraceae in Malarial to 6\%, and this was tested in an observational cohort study of patients with uncomplicated malaria [66]. Thirty patients were included, aged 5 years or above, with a temperature of $>37.5^{\circ} \mathrm{C}$ and a parasitaemia of $>3000$ per mcl P. falciparum. There was no control group. Parasitaemia declined (from a geometric mean of 5465 at day 0 to 629 at day 7) and symptoms 
improved. Parasitaemia at day 7 remained higher in patients aged 8-19 years than in older patients. This suggests that patient immunity was playing a role in clearing the parasites.

\section{N'dribala (Cochlospermum planchonii}

Hook. f. ex Planch. [Bixaceae])

Development and use of the phytomedicine: A decoction of the roots of Cochlospermum planchonii Hook. f. ex Planch. (Bixaceae) is traditionally used for the treatment of fevers and malaria in Burkina Faso [67], Ivory Coast [68], Niger [69], and Nigeria [70]. A company in Burkina Faso (Phytofla, Inc.) produces sachets of $70 \mathrm{~g}$ of Cochlospermum planchonii root, sold as an improved traditional medicine in pharmacies, which obtained government approval in Burkina Faso in 2005. It is estimated that over 85000 patients are treated with this preparation every year. Conservation measures are needed to protect the wild sources of this plant.

Phytochemistry and pharmacology: In vitro the $\mathrm{IC}_{50}$ of antiplasmodial activity of Cochlospermum planchonii aqueous root decoction against chloroquine-sensitive and chloroquine-resistant strains of Plasmodium falciparum was $75 \mu \mathrm{g} / \mathrm{mL}$ [71]. Cytotoxicity in vitro was low (Francoise Benoit-Vical, personal communication).

Clinical trial: "N'dribala" was evaluated in the clinical treatment of uncomplicated falciparum malaria in Banfora Hospital, Burkina Faso [67] (๑ Table 3). 46 patients on N'dribala were compared to 21 treated with chloroquine (which was at the time the standard treatment, with $12 \%$ of patients experiencing clinical resistance). Both treatments resulted in similar parasite clearance rates at day 5 (52\% and 57\%, respectively) although more patients on N'dribala remained febrile at day 5. Only minor side effects were reported in both groups.

\section{Soumafoura Tiemoko Bengaly}

(Argemone mexicana L. [Papaveraceae])

Development and use of the phytomedicine: Argemone mexicana $\mathrm{L}$. (Papaveraceae) is a pantropical weed with a long history of use in traditional medicine, dating back to the Aztecs [72]. It is used as an antimalarial in several African countries, including Benin, Mali, and Sudan [73-75].

It is currently being developed as a standardized phytomedicine by the Department for Traditional Medicine in Mali, and named after the traditional healer Tiemoko Bengaly who has participated in its development ( $\bullet$ Fig. 4). The current official phytomedicine (Malarial-5) is felt not to be sufficiently effective and has never been trialled in children [59]. In the quest for a new official phytomedicine, two large areas of the south-east of Mali were surveyed. A retrospective treatment-outcome study was conducted to identify the herbal preparation most often correlated with successful outcomes in cases of presumed malaria [75-77]. The most promising herbs were also tested in vitro, and Argemone mexicana had the greatest antimalarial activity [75]. The decoction was then studied in a prospective dose escalating clinical trial following a local recipe in patients with uncomplicated malaria. This found a dose-response correlation and a good safety profile [78]. The optimal dose was then compared in a randomized controlled trial to artesunate-amodiaquine for the home-based management of presumed malaria [79]. Following positive results, it is being considered for approval as an "Improved Traditional Medicine" for malaria in Mali, to supercede the current Malian ITM for malaria ("Malarial-5").

Phytochemistry and pharmacology: $\mathrm{IC}_{50}$ values of the aerial parts of this plant against the chloroquine-resistant K1 strain of Plas- modium falciparum were 5.89 and $1.00 \mu \mathrm{g} / \mathrm{mL}$ for the aqueous decoction and methanol extracts, respectively [75]. The plant contains several alkaloids with in vitro antimalarial activity, including berberine, allocryptopine, and protopine [80]. However animal studies suggest that the crude aqueous extract is not effective against $P$. berghei, and that berberine is not well absorbed orally (Falquet, unpublished data). Studies are underway to identify which compounds are active in humans.

Clinical trials: These were the only trials of ITMs included in this review which reported the rate of adequate clinical response (ACR), which is the outcome measure recommended by the World Health Organization [81,82], and adapted by RITAM for the assessment of herbal remedies [83]. ACR occurred in only $35 \%$ of patients treated with a low dose (one dose daily for three days), compared to $72.5 \%$ of patients treated with a higher dose (twice daily for seven days). Although parasite counts decreased, they were cleared completely in only $9 \%$ of patients [78]. The randomized controlled trial in 300 patients with presumed malaria showed that the remedy is safe and well tolerated, even in children. $89 \%$ of patients recovered clinically, although the proportion of patients with parasitaemia at day 28 was $63-76 \%$ in the AM group and $21-49 \%$ in the ACT group. Deterioration to severe malaria was $1.9 \%$ in both groups in children aged $\leq 5$ years (there were no cases in patients aged $>5$ years) and $0 \%$ had coma/convulsions [79]. Patients were followed for three months to see whether the lack of parasite clearance would be a problem. From day 29 to day 84, there were no significant differences between treatment groups in the incidence of new uncomplicated malaria ( 0.33 vs. 0.31 episodes/patient), severe malaria (<6\% per month of patients aged $\leq 5$ years) or moderate anaemia (hematocrit <24\%: $1.1 \%$ in both groups at d84). Total parasite clearance at day 28 was not correlated with incidence of uncomplicated or severe malaria or of moderate anaemia over the subsequent two months [84].

\section{Discussion}

$\nabla$

The seven phytomedicines presented here are only a small fraction of the huge potential for development of herbal medicines for malaria. Many other remedies have never been researched thoroughly in spite of strong anecdotal evidence of safety and efficacy. Further research is needed, both on the phytomedicines reported here and on new potential phytomedicines. Although these phytomedicines are produced according to standard recipes, in most cases their quality (in terms of key phytochemicals) is not controlled. Clinical trials have often been small and of variable quality. Except for trials of Argemone mexicana, they have excluded young children, who are those at greatest risk of malaria. In semi-immune adults, it is expected that many patients will improve even without treatment, so it is possible that the reported efficacy rates are greater than would be observed in nonimmune patients. These results should be interpreted with care and not extrapolated inappropriately.

It is useful to have a range of evidence-based options for use in "green pharmacies" because no plant will grow well in all conditions. Artemisia annua grows well in many tropical areas but needs adequate rainfall and some shade. It does not grow well in semi-arid areas, where Argemone mexicana thrives.

What is the best way of prioritising other plants or remedies for development into phytomedicines? Except for the case of Argemone mexicana, which was selected following a logical process 
of prioritisation among available antimalarial plants in Southern Mali [76], the other phytomedicines were developed more as a result of historical circumstances. However, now it is known that over 1200 plant species are used worldwide for the treatment of malaria and fevers, and many have been tested in vitro and/or in vivo. RITAM has developed a score taking into account existing ethnobotanical and laboratory data to prioritise remedies for future development [85].

In this process it is important to start out with traditional methods of preparation which have been found empirically to be effective. Recent experiments have shown that traditional methods of soaking and crushing produce the most concentrated extracts of Artemisia annua [19]. However subsequent research has shown that an ethanolic extract may be a good alternative. Ayush-64, which turned out not to be very effective, is not really an Ayurvedic treatment for malaria. It was produced by scientists from traditional plants but using modern methods which are far removed from the traditional preparation, and may have destroyed active ingredients.

What are the most appropriate outcome measures for clinical trials of herbal antimalarials? As shown in $\odot$ Table 3, most trials to date have used parasite clearance at day $5-7$ as the principle outcome measure. Parasite clearance is important in low transmission areas where patients are not readily re-infected and have little or no immunity to malaria. In areas of high malaria transmission, populations develop a level of immunity to malaria by the age of five years, and re-infection happens fast, so the importance of parasite clearance is debatable. Furthermore, the accurate confirmation of parasite clearance requires high-quality microscopy, and it is not clear that this was used in all the trials. Adequate clinical response (ACR) is a composite outcome measure which requires the patient to be afebrile and/or clear of parasites at day 14 , without previously having any danger signs or treatment failure $[81,82]$. WHO first recommended ACR as the best outcome measure for clinical trials on uncomplicated malaria in 1996 [82], so it was never used in trials before then, and was not even used in all subsequent trials. The prevention of severe malaria and death are the most important outcomes but require large sample sizes, larger than practical in many trials. A sample size of 300 patients was required to show that there was no significant difference in these outcomes between patients treated with Argemone mexicana decoction and those treated with artesunate/amodiaquine [79]. Interestingly, the herbal medicine prevented severe malaria and death without totally clearing parasites [79,84].

Safety outcomes are equally important. While caution is important, dangers are sometimes overplayed by opponents of herbal medicine. It is important to remember the ancient dictum "sola dosis facit venenum": only the dose makes a poison. It is easy to be scared by the "toxic" constituents of plants, but most effective medicines are toxic if given at too high a dose. The time-honoured antimalarial quinine is highly toxic in overdose. In contrast Artemisia annua and Argemone mexicana are remarkably safe. Some researchers have expressed doubts about the continued use of Cryptolepis sanguinolenta extracts because of the cytotoxicity of cryptolepine, and it seems from animal experiments that long-term use may indeed lead to hepatotoxicity. However, when used as a short-term treatment for one or two weeks, there is no observed toxicity. Further clinical trials should carefully monitor markers of toxicity (in particular liver function tests), and data is needed on the absorption, metabolism and excretion of the alkaloids of $C$. sanguinolenta.
Some scientists view plants purely as a source of new compounds, to be developed into modern pharmaceuticals. Why then do totaquina and qing hao remain in use as herbal remedies, when highly effective chemical compounds have been isolated and developed as pharmaceuticals from these plants? Firstly, the herbal remedies can be produced locally, and are thus more readily available, affordable, and sustainable than manufactured medicines. Secondly, (especially in the case of totaquina) the herbal remedy may be better tolerated, with fewer side effects than the pharmaceutical. Thirdly, the herbal remedies are natural combinations, containing several antimalarial constituents and therefore may delay the development of resistance. Fourthly, they may be as effective as pure compounds. All the available evidence suggests that crude extracts of Cinchona bark, in spite of variability in composition, are as effective as quinine in the treatment of both $P$. vivax and $P$. falciparum malaria, and indeed may be more effective in areas where $P$. falciparum has evolved resistance to quinine. There is also mounting evidence that Artemisia annua herbal preparations have greater efficacy and bioavailability than equivalent doses of pure artemisinin.

In the context of the current public health war on malaria, is there still a role for phytomedicines? It is an unwise general who discards any weapons from his arsenal. While ACTs are highly efficacious they still cannot easily be deployed, reliably and consistently, in all malarious areas. Supplies are likely always to be limited, so it makes sense to keep ACTs for those at greatest risk (children and pregnant women) while using phytomedicines as a first-line for lower risk patients. Many areas have only intermittent supplies of ACTs with more or less frequent stock-outs. Other areas are still beyond the reach of drug distribution networks. In such areas a "green pharmacy" may help to provide a sustainable solution in the short to medium term.

\section{References}

1 WHO. Guidelines for the treatment of malaria, 2nd edition. Geneva: World Health Organization; 2010

2 Breman JG. The ears of the hippopotamus: manifestations, determinants, and estimates of the malaria burden. Am J Trop Med Hyg 2001; 64: $1-11$

3 Willcox M, Burford G, Bodeker G. An overview of ethnobotanical studies on plants used for the treatment of malaria. In: Willcox M, Bodeker G, Rasoanaivo P, editors. Traditional medicinal plants and malaria. Boca Raton: CRC Press; 2004: 187-197

4 Willcox ML, Bodeker G. Traditional herbal medicines for malaria. BMJ 2004; 329: 1156-1159

5 Willcox M, Bodeker G, Rasoanaivo P. Traditional medicinal plants and malaria. Boca Raton: CRC Press; 2004

6 Harper D. Early Chinese medical literature: the Mawangdui medical manuscripts. London: Routledge; 1998

7 Hsu E. The history of qing hao in the Chinese materia medica. Trans $\mathrm{R}$ Soc Trop Med Hyg 2006; 100: 505-508

8 Delabays N. Biologie de la réproduction chez l'Artemisia annua L. et génétique de la production en artémisinine. Lausanne: Université de Lausanne; 1997

9 Hirt H, M'Pia B. Natural medicine in the tropics I. Winnenden: Foundation Text Anamed; 2008

10 Wan $Y$, Zhang $Q$ Wang J. Studies on the antimalarial action of gelatin capsule of Artemisia annua. Chung Kuo Chi Sheng Chung Hsueh Yu Chi Sheng Chung Ping Tsa Chih 1992; 10: 290-294

11 Bonati M, Severino F, Bagnati R, Carrà A, Fanelli R. Millet-porridge with Artemisia annua as first aid for African children with malaria? J Altern Complement Med, in press

12 Bhakuni R, Jain D, Sharma R. Phytochemistry of Artemisia annua and the development of artemisinin-derived antimalarial agents. In: Wright C, editor. Artemisia. London: Taylor \& Francis; 2002

13 Tan RX, Zheng WF, Tang HQ. Biologically active substances from the genus Artemisia. Planta Med 1998; 64: 295-302 
14 Chang H, But P. Pharmacology and applications of Chinese Materia Medica. Singapore: World Scientific Publishing; 1986

15 Liu K-S, Yang S-L, Roberts M, Elford B, Phillipson J. Antimalarial activity of Artemisia annua flavonoids from whole plants and cell cultures. Plant Cell Reports 1992; 11: 637-640

16 Elford BC, Roberts MF, Phillipson JD, Wilson RJ. Potentiation of the antimalarial activity of qinghaosu by methoxylated flavones. Trans R Soc Trop Med Hyg 1987; 81: 434-436

17 Rath K, Taxis K, Walz G, Gleiter CH, Li SM, Heide L. Pharmacokinetic study of artemisinin after oral intake of a traditional preparation of $\mathrm{Ar}$ temisia annua L. (annual wormwood). Am J Trop Med Hyg 2004; 70: 128-132

18 De Magalhães P, Debrunner N, Delabays N. Aqueous extracts of Artemisia апnиa L. International Conference on Malaria: Current status and future trends, Chulabhorn Research Institute, Bangkok, Thailand; 2003

19 Wright CW, Linley PA, Brun R, Wittlin S, Hsu E. Ancient Chinese methods are remarkably effective for the preparation of artemisinin-rich extracts of Qing Hao with potent antimalarial activity. Molecules 2010; 15: 804-812

20 Atemnkeng MA, Chimanuka B, Dejaegher B, Heyden YV, Plaizier-Vercammen J. Evaluation of Artemisia annua infusion efficacy for the treatment of malaria in Plasmodium chabaudi chabaudi infected mice. Exp Parasitol 2009; 122: 344-348

21 Wilairatana $P$, Looaresuwan $S$. The clinical use of artemisinin and its derivatives in the treatment of malaria. In: Wright CW, editor. Artemisia. London: Taylor \& Francis; 2002

22 WHO. The use of artemisinin \& its derivatives as anti-malarial drugs. Geneva: Malaria Unit, Division of Control of Tropical diseases, WHO; 1998

$23 \mathrm{WHO}$. The role of artemisinin and its derivatives in the current treatment of malaria (1994-1995). Geneva: WHO; 1994

24 Willcox M. Artemisia species: from traditional medicines to modern antimalarials-and back again. J Altern Complement Med 2009; 15: 101-109

25 Willcox M, Burton S, Lindsey K. Evaluation and pharmacovigilance of projects promoting cultivation and local use of Artemisia annua for malaria. In preparation

26 Honigsbaum M, Willcox ML. Cinchona. In: Willcox ML, Bodeker G, Rasoanaivo P, editors. Traditional medicinal plants and malaria. Boca Raton: CRC Press; 2004: 21-41

27 Jarcho S. Quinine's predecessor, Francesco Torti and the early history of cinchona. Baltimore: John Hopkins University Press; 1993

28 Duran-Reynals MLDA. The fever bark tree: the pageant of quinine. New York: Doubleday; 1946

29 Honigsbaum $M$. The fever trail: the hunt for the cure for malaria. London: Macmillan; 2001

30 OUA. Pharmacopée Africaine. Lagos: Organisation de l'Unité Africaine; 1985

31 Karle JM, Bhattacharjee AK. Stereoelectronic features of the Cinchona alkaloids determine their differential antimalarial activity. Bioorg Med Chem 1999; 7: 1769-1774

32 Druilhe P, Brandicourt O, Chongsuphajaisiddhi T, Berthe J. Activity of a combination of three Cinchona bark alkaloids against Plasmodium falciparum in vitro. Antimicrob Agents Chemother 1988; 32: 250-254

33 Solary E, Mannone L, Moreau D, Caillot D, Casasnovas RO, Guy H, Grandjean M, Wolf JE, Andre F, Fenaux P, Canal P, Chauffert B, Wotawa A, Bayssas $M$, Genne $P$. Phase I study of cinchonine, a multidrug resistance reversing agent, combined with the CHVP regimen in relapsed and refractory lymphoproliferative syndromes. Leukemia 2000; 14: 20852094

34 Frappier F, Jossang A, Soudon J, Calvo F, Rasoanaivo P, Ratsimamanga-Urverg S, Saez J, Schrevel J, Grellier P. Bisbenzylisoquinolines as modulators of chloroquine resistance in Plasmodium falciparum and multidrug resistance in tumor cells. Antimicrob Agents Chemother 1996; 40: 14761481

35 Pampana E. Clinical tests carried out under the auspices of the malaria commission. League of Nations: Quarterly Bulletin of the Health Organisation 1934; III: 328-343

36 Fletcher $W$. Critical analysis of the results achieved. League of Nations: Quarterly Bulletin of the Health Organisation 1934; III: 344-358

37 Hicks EP, Diwan Chand S. The relative clinical efficacy of totaquina and quinine. Records of the Malaria Survey of India 1935; 5: 39-50

38 White NJ, Looareesuwan S, Warrell DA, Chongsuphajaisiddhi T, Bunnag D, Harinasuta T. Quinidine in falciparum malaria. Lancet 1981; 2: 1069-1071
39 MacGilchrist A. The relative therapeutic value in malaria of the cinchona alkaloids quinine, cinchonine, quinidine, cinchonidine and quinoidine, and the two derivatives - hydroquinine and ethylhydrocupreine. Indian J Med Res 1915; III: 1-53

40 Sinton J, Bird W. Studies in malaria, with special reference to treatment. Part XI: the Cinchona alkaloids in the treatment of benign tertian malaria. Indian J Med Res 1929; 16: 725-746

41 Bunnag D, Harinasuta T, Looareesuwan S, Chittamas S, Pannavut W, Berthe J, Mondesir JM. A combination of quinine, quinidine and cinchonine (LA 40221) in the treatment of chloroquine resistant falciparum malaria in Thailand: two double-blind trials. Trans R Soc Trop Med Hyg 1989; 83: 66

42 Mshana NR, Abbiw DK, Addae-Mensah I, Adjanouhoun E, Ahyi MRA, Ekpere JA, Enow-Orock EG, Gbile ZO, Noamesi GK, Odei MA, Odunlami $H$, Oteng-Yeboah AA, Sarpong K, Sofowora A, Tackie AN. Traditional medicine and pharmacopoeia: Contribution to the revision of ethnobotanical and floristic studies in Ghana. Lagos: Organisation of African Unity/ Scientific, Technical and Research Commission; 2000

43 Tona L, Ngimbi NP, Tsakala M, Mesia K, Cimanga K, Apers S, De Bruyne T, Pieters L, Totte J, Vlietinck AJ. Antimalarial activity of 20 crude extracts from nine African medicinal plants used in Kinshasa, Congo. J Ethnopharmacol 1999; 68: 193-203

44 Boye GL, Ampofo O. Clinical uses of C. sanguinolenta. Proceedings of the First International Seminar on Cryptolepine, Kumasi, Ghana; 1983

45 Addy M. Cryptolepis: an African traditional medicine that provides hope for malaria victims. Herbalgram 2003; 60: 54-59

46 Addae-Kyreme J. Cryptolepis sanguinolenta. In: Willcox ML, Bodeker G, Rasoanaivo P, editors. Traditional medicinal plants and malaria. Boca Raton: CRC Press; 2004: 131-139

47 Sarpong K. Morphology and alkaloid distribution in Cryptolepis sanguinolenta. First International Seminar on Cryptolepine, University of Science and Technology, Kumasi, Ghana; 1983: 15-22

48 Wright CW, Addae-Kyereme J, Breen AG, Brown JE, Cox MF, Croft SL, Gokcek Y, Kendrick H, Phillips RM, Pollet PL. Synthesis and evaluation of cryptolepine analogues for their potential as new antimalarial agents. J Med Chem 2001; 44: 3187-3194

49 Kirby GC, Paine A, Warhurst DC, Noamese BK, Phillipson JD. In vitro and in vivo antimalarial activity of cryptolepine, a plant-derived indoloquinoline. Phytother Res 1995; 9: 359-363

50 Bonjean K, De Pauw-Gillet MC, Defresne MP, Colson P, Houssier C, Dassonneville L, Bailly C, Greimers R, Wright C, Quetin-Leclercq J, Tits M, Angenot $L$. The DNA intercalating alkaloid cryptolepine interferes with topoisomerase II and inhibits primarily DNA synthesis in B16 melanoma cells. Biochemistry 1998; 37: 5136-5146

51 Dassonneville L, Lansiaux A, Wattelet A, Wattez N, Mahieu C, Van Miert S, Pieters L, Bailly C. Cytotoxicity and cell cycle effects of the plant alkaloids cryptolepine and neocryptolepine: relation to drug-induced apoptosis. Eur J Pharmacol 2000; 409: 9-18

52 Ansa-Asamoah R, Frempong-Asante J. Preliminary studies on the short term toxicity of cryptolepine in mice. Proceedings of the First International Seminar on Cryptolepine, Kumasi, Ghana; 1983: 52-55

53 Boye GL. Studies on the antimalarial action of Cryptolepis sanguinolenta extract. International Symposium on East-West Medicine, Seoul, Korea; 1989: 242-251

54 Sharma V. Ayush-64. In: Willcox M, Bodeker G, Rasoanaivo P, editors. Traditional medicinal plants and malaria. Boca Raton: CRC Press; 2004: 83-89

55 CCRAS. Ayush-64: A new Ayurvedic anti-malarial compound. New Delhi: Central Council for Research in Ayurveda and Siddha, Ministry of Health and Family Welfare, Government of India; 1987: 128

56 Valecha N, Devi C, Joshi H, Shahi V, Sharma V, Lal S. Comparative efficacy of Ayush-64 vs. chloroquine in vivax malaria. Curr Sci 2000; 78: 11201122

57 Sharma KD, Kapoor ML, Vaidya SP, Sharma L. A clinical trial of "Ayush64" (a coded antimalarial medicine) in cases of malaria. J Res Ayurveda Siddha 1981; II: 309-326

58 Anon. Formulaire National Thérapeutique. Bamako: Ministère de la Santé, des Personnnes Agées et de la Solidarité; 1998

59 Diallo D, Maiga A, Diakite C, Willcox M. Malarial-5: Development of an antimalarial phytomedicine in Mali. In: Willcox M, Bodeker G, Rasoanaivo P, editors. Traditional medicinal plants and malaria. Boca Raton: CRC Press; 2004 
60 Iwalewa EO, Lege-Oguntoye L, Rai PP, Iyaniwura TT, Etkin NL. In vitro antimalarial activity of leaf extracts of Cassia occidentalis and Guiera senegalensis in Plasmodium yoelii nigeriensis. West Afr J Pharmacol Drug Res 1990; 9: 19-21

61 Kerharo J, Adam JG. La pharmacopée sénégalaise traditionnelle. Plantes médicinales et toxiques. Paris: Vigot Frères; 1974

62 Jellal A, Lemerre S, Michot P, Oger R, Rabiller P. Le Spilanthes. Dijon: Etablissement National d'Enseignement Supérieur Agronomique (ENESA); 1998

63 Gasquet M, Delmas F, Timon-David P, Keita A, Guindo M, Koita N, Diallo $D$, Doumbo 0 . Evaluation in vitro and in vivo of traditional antimalarial, "Malarial 5". Fitoterapia 1993; 64: 423-426

64 Koita N. A comparative study of the traditional remedy "Suma-Kala" and chloroquine as treatment for malaria in the rural areas. In: Mshigeni KE, Nkunya MHH, Fupi V, Mahunnah RLA, Mshiu E, editors. Proceedings of an International Conference of Experts from Developing Countries on Traditional Medicinal Plants. Arusha, Tanzania: Dar Es Salaam University Press; 1990: 68-82

65 Kéita A, Doumbo O, Koïta N, Diallo D, Guindo M, Traoré AK. Recherche expérimentale sur un anti-malarique traditionnel. "Etude préliminaire sur la faisabilité d'un protocole d'essai clinique". Bulletin de Médecine Traditionnelle et Pharmacopée 1990; 4: 139-146

66 Doumbia S. Etude des plantes antipaludiques au Mali. Bamako: Universite de Bamako, Faculte de Medecine, Pharmacie et Odonto-Stomatologie; 1997: 78

67 Benoit-Vical F, Valentin A, Da B, Dakuyo Z, Descamps L, Mallie M. N'Dribala (Cochlospermum planchonii) versus chloroquine for treatment of uncomplicated Plasmodium falciparum malaria. J Ethnopharmacol 2003; 89: 111-114

68 Vonthron-Senecheau C, Weniger B, Ouattara M, Bi FT, Kamenan A, Lobstein $A$, Brun $R$, Anton $R$. In vitro antiplasmodial activity and cytotoxicity of ethnobotanically selected Ivorian plants. J Ethnopharmacol 2003; 87: 221-225

69 Adam JG, Echard N, Lescot M. Plantes médicinales Hausa de l'Ader (République du Niger). J Agric Trop Bot Appl 1972; XIX: 259-399

70 Etkin NL, Ross PJ. Recasting malaria, medicine and meals: A perspective on disease adaptation. In: Romanucci-Ross L, Moerman DE, Tancredi LR, editors. The anthropology of medicine: from culture to method. New York: Bergin \& Garvey; 1991: 230-258

71 Benoit-Vical F. Evaluation de l'activité antimalarique in vitro de divers extraits végétaux bruts et purifiés sur Plasmodium falciparum. Montpellier: Université Montpellier I; 1997

72 Emmart E. The Badianus Manuscript: an Aztec herbal of 1552. Baltimore: John Hopkins Press; 1940

73 Guindo M. Contribution à l'étude du traitement traditionnel du "suma" (paludisme). Bamako: Universite de Bamako, École Nationale de Médecine et de Pharmacie du Mali; 1988

74 Adjobimey T, Edayé I, Lagnika L, Gbenou J, Moudachirou M, Sanni A. Activités antiplasmodiales in vitro de quelques plantes antipaludiques de la pharmacopée béninoise. C R Chimie 2004; 7: 1023-1027

75 Diallo D, Diakite C, Mounkoro PP, Sangare D, Graz B, Falquet J, Giani S. [Knowledge of traditional healers on malaria in Kendi (Bandiagara) and Finkolo (Sikasso) in Mali]. Mali Med 2007; 22: 1-8

76 Diallo D, Graz B, Falquet J, Traore AK, Giani S, Mounkoro PP, Berthe A, Sacko M, Diakite C. Malaria treatment in remote areas of Mali: use of modern and traditional medicines, patient outcome. Trans R Soc Trop Med Hyg 2006; 100: 515-520
77 Graz B, Diallo D, Falquet J, Willcox M, Giani S. Screening of traditional herbal medicine: first, do a retrospective study, with correlation between diverse treatments used and reported patient outcome. J Ethnopharmacol 2005; 101: 338-339

78 Willcox ML, Graz B, Falquet J, Sidibe O, Forster M, Diallo D. Argemone mexicana decoction for the treatment of uncomplicated falciparum malaria. Trans Roy Soc Trop Med Hyg 2007; 101: 1190-1198

79 Graz B, Willcox M, Diakite C, Falquet J, Dakouo F, Sidibe O, Giani S, Diallo D. Argemone mexicana decoction versus Artesunate/Amodiaquine for the home-based management of malaria in Mali. Policy and public health implications. Trans R Soc Trop Med Hyg 2010; 104: 33-41

80 Simoes-Pires CA. Investigation of antiplasmodial compounds from various plant extracts: Argemone mexicana L. (Papaveraceae), Licania octandra (Hoffmanns. ex. Roem \& Schult) Kuntze (Chrysobalanaceae) and Syzygium cumini (L.) Skeels (Myrtaceae). Geneva: Universite de Geneve, Section des Sciences Pharmaceutiques, Laboratoire de Pharmacognosie et Phytochimie; 2009

81 WHO. Assessment and monitoring of antimalarial drug efficacy for the treatment of uncomplicated falciparum malaria. Geneva: World Health Organization; 2003

82 WHO. Assessment of therapeutic efficacy of antimalarial drugs for uncomplicated falciparum malaria in areas with intense transmission. WHO/MAL/96.1077. Geneva: World Health Organization; 1996

83 Willcox M, Olanrewaju I. Guidelines for clinical studies on herbal antimalarials. In: Willcox M, Bodeker G, Rasoanaivo P, editors. Traditional medicinal plants and malaria. Boca Raton: CRC Press; 2004

84 Willcox M, Graz B, Diakite C, Falquet J, Dackouo F, Sidibe O, Giani S, Diallo $D$. Is parasite clearance clinically important after malaria treatment in a high transmission area? A 3-month follow-up of home-based management with herbal medicine or ACT. Trans R Soc Trop Med Hyg 2011; 105: 23-31

85 Willcox ML, Benoit-Vical F, Fowler D, Bourdy G, Burford G, Giani S, Graziose R, Houghton P, Randrianarivelojosia M, Rasoanaivo P. Do ethnobotanical and laboratory data predict clinical safety and efficacy of antimalarial plants? Mal J, in press

86 Benoit-Vical F, Soh PN, Salery M, Harguem L, Poupat C, Nongonierma R. Evaluation of Senegalese plants used in malaria treatment: focus on Chrozophora senegalensis. J Ethnopharmacol 2008; 116: 43-48

87 do Ceu de Madureira M, Paula Martins A, Gomes M, Paiva J, Proenca da Cunha A, do Rosario V. Antimalarial activity of medicinal plants used in traditional medicine in S. Tome and Principe islands. J Ethnopharmacol 2002; 81: 23-29

88 Kazim M, Puri SK, Dutta GP, Narasimham MV. Evaluation of Ayush-64 for blood schizontocidal activity against rodent and simian malaria parasites. Indian J Malariol 1991; 28: 255-258

89 Mueller MS, Runyambo N, Wagner I, Borrmann S, Dietz K, Heide L. Randomized controlled trial of a traditional preparation of Artemisia annua L. (Annual Wormwood) in the treatment of malaria. Trans R Soc Trop Med Hyg 2004; 98: 318-321

90 Mueller MS, Karhagomba IB, Hirt HM, Wemakor E. The potential of Artemisia annua $\mathrm{L}$. as a locally produced remedy for malaria in the tropics: agricultural, chemical and clinical aspects. J Ethnopharmacol 2000; 73: 487-493

91 Hirt H-M, Lindsey K. Natural medicine in the tropics: Experiences. Winnenden: Anamed; 2000 